documents, of which British Postal Orders suspected of alteration are by far the most numerous. Betting letters have also been examined for reasons which Dr. Lewis gives as follows.

"Every year disillusioned punters conclude that betting would be profitable if conducted after results of races were known and the rule that postal bookmakers accept bets postmarked before starting times tends to spur some misguided individuals to ingenious action". Most of this forensic work involves examination of documents by ultra-violet radiation and often requires that members of the Laboratory staff must act as witnesses in those cases which come before the law courts.

Certain matters of public health are also referred to the Laboratory, which undertakes examinations of water and sewage for various authorities, but principally the Ministries of Health, and Housing and Local Governmont. One particular national problem concerns the disposal of some 11 million tons of household refuse each year in England and Walesequivalent to 5 cwt. per person per year. The tipping of this refuse in disused gravel pits and other dumping grounds can lead to pollution of underground and surface water supplies. The Laboratory has made careful studies of the degrees of pollution which can occur and its results have been passed to the Ministry of Housing and Local Government, with recommendations for a continued study of the problem in collaboration with local authoritios and water undertakings.

An increasing part of the work of the Laboratory is concerned with long-term research work on specialized matters such as radioactive fall-out and effluents from nuclear power plants. The develop- ment of new analytical methods using physical techniques such as $\mathrm{X}$-ray diffraction and $\mathrm{X}$-ray fluorescent spectroscopy is also continuing. These physical methods have advantages where a non-destructive examination is required.

There has, however, been a need in the Laboratory for a group to undertake research on problems of a more general nature. With this in mind, a new division of the General Methods Research Committee has been formed the purposes of which are to review existing methods of analysis and to develop new ones for the variety of materials with which the Laboratory is concerned in its day-to-day work. In this connexion, excellent work has been done on the detection and identification of a large number of organic pesticide chemicals using mainly the techniques of paper chromatography and infra-red spectroscopy. Each year the Laboratory has to undertake an appreciable amount of investigatory work connected with the possible hazards not only to humans but also to wild-life which arise from the extensive use of pesticide chemicals in agriculture; the wide range of these chemicals now commercially available must be readily identifiable in all sorts of animal and vegetable matter.

The reports of the Government Chemist are always of considerable interest and the present one is no exception. For sheer diversity of content there is little with which to compare it; for where else could one find an account of the detection of the pesticide 'Aldrin' in a sample of rice pudding, or the involved radiochemical investigations arising from nuclear fall-out. The Laboratory exists to safeguard the public; this report leaves no doubt that it is work well done.

W. I. Stephen

\title{
FIFTH INTER-AMERICAN SYMPOSIUM ON COSMIC RADIATION
}

T was perhaps rather fitting that the staff of the Iorld's highest cosmic ray laboratory should play host to the experts of the fourteen nations who contributed to the Symposium on Cosmic Radiation in La Paz, Bolivia, during July 17-27. This laboratory, situated at Mt. Chacaltaya some $35 \mathrm{~km}$ from La Paz, is rapidly becoming one of the foremost centres of high-altitude research. The altitude of the laboratory is $17,600 \mathrm{ft}$. , and as such affords an ideal site for recording cosmic radiation and observing the night sky. Among its equipment is a cosmic ray air shower-recording array the central detector of which has an area of $60 \mathrm{~m}^{2}$ and is shielded by 400 tons of lead ore.

After the formal opening by the President of Bolivia, whose speech stressed the contribution that this scientific endeavour was making in combating the conditions of under-development in the country, inaugural speeches by Prof. Vallarta from Mexico, Dr. Establier of Unesce and the rector of the University of La Paz, omphasized the amount of international co-operation involved in the work going on in Bolivia. Scientists from Brazil, Bolivia, Great Britain, India, Japan and the United States are now working in the Chacaltaya Observatory. Thanks to aid from Unesco, the U.S. Office of Scientific Research, and the International Union of Pure and Applied Physics, it was possible to gather in La Paz some of the foremost authorities on cosmic radiation for the Fifth InterAmerican Symposium.
It is not possible in such a short summary to do justice to the enormous amount of interesting and significant contributions made by the various speakers in the symposium. Sixty-four papers were presented, and covered such fields as the measurement of the prehistoric cosmic radiation flux to the latest satellite measurements made by the U.S. National Astronautical and Space Administration. Russian speakers described experiments going on in the Crimea for the detection of Cerenkov radiation produced by $\gamma$-rays coming from other galaxies. The subject of $\gamma$-ray astronomy was well covered by the Massachusetts Institute of Technology groups working in New Mexico and their associates working in Chacaltaya in conjunction with colleagues from the Universities of Tokyo and La Paz. The subject of time variations was well covered by the speakers, and in this field, as well as geomagnetism, one appreciated the tremendous activity now going on in Latin America in the realm of geophysics. South America to-day supports a number of flourishing research organizations, all of which made significant contributions to the Symposium; among them may be mentioned the timevariation groups in Rio de Janeiro, Buenos Aires, geomagnetic observatory in Huancayo, Peru, and the emulsion work at São Paulo, Brazil, and Tucuman, Argentina. The Symposium illustrated the enormous increase that has been made in our knowledge of the conditions in the space surrounding the Earth as well as the conception of the universe as a whole. 
In addition to the scientific activities, a number of interesting social events and excursions was arranged which included a trip to the Inca ruins at Tihuanaco and an airborne excursion to the headwaters of the Amazon, by courtesy of the Bolivian Air Force.

No such gathering would have been possible but for the existence of the Laboratorio de Física Cósmica at Chacaltaya, to the director of which, Prof. Ismael Escobar, goes the credit for its foundation and expansion into its now pre-eminent position as a high-altitude observatory, where many nations co-operate to discover some of the characteristics of the space in which we move.

C. J. BLAND

\section{NEW NATURE RESERVES AND EXTENSIONS IN ENGLAND AND SCOTLAND}

$\mathrm{T}$ HE Nature Conservancy declared the following new National Nature Reserves and extensions on September 28:

\section{ENGLAND}

\section{Colt Park Wood, Yorkshire}

This Reserve, at Ribblehead in the Craven Pennines, has been purchased by the Nature Conservaney and is a 21-acre strip of ash wood growing on a narrow, mile-long scar on the lower slopes of the north-east face of Ingleborough, at a height of $1,100 \mathrm{ft}$. It is only about $1 \frac{1}{2}$ miles from Ling Gill National Nature Reserve which was declared in 1958. The Reserve, which is in the Yorkshire Dales National Park, contains one of the few remaining examples of highlevel ash wood on limestone pavement. The northern part is dominated by ash varying in height from 25 to $40 \mathrm{ft}$. Other tree species include bird cherry, silver birch, rowan and hazel. The trees grow directly on the limestone, rooting in the fissures or 'grikes' which dissect the pavement deeply. Farther south along the scar the wood thins out and the clints are devoid of plant cover although a 'woodland' ground flora persists in the shelter of the grikes. The ground flora throughout the Reserve is most striking and a number of rare species is present. For a long time the wood has been valued for its shelter in an otherwise almost tree-less landscape, a fact which may explain its survival; but it has suffered extensively from grazing and little tree regeneration is taking place. The first step in management, therefore, will be to fence the Reserve to encourage fresh tree growth to replace the present ageing canopy.

Access is by permit only. Applications to visit or for permission to undertake research or to collect specimens of plants or animals should be addressed to the Regional Officer for the North Merlowood Research Station, Grange-over-Sands, Lancashire.

\section{Blean Woods (Grimshill Wood Extension) Kent}

The first part of this Reserve was declared in 1953, and a small portion added in 1959 brought the Reservo up to 81 acres. A further 84 acres, known as Grimshill Wood, have been purchased. The Reserve consists almost entirely of oak woodland with a variety of coppice species, but there is considerable diversity in the area owing to the different types of management to which each part has been subjected. That part previously declared had been undor management for coppice, whereas the newly acquired portion has been cut much less frequently and the coppice is therefore larger and older. The new area will be suitable for relatively quick conversion to highcanopy woodland, and will thus enable some of the previously declared part of the Reserve to be released for short rotation coppice management for which it is better suited.

Application for permits to visit parts of the Reserve away from public footpaths should be addressed to the Regional Officer for the South-East, the Nature Conservancy, 19 Belgrave Square, London, S.W.1.

\section{SCOTLAND}

\section{St. Cyrus, Angus and Kincardineshire}

The St. Cyrus National Nature Reserve occupies 227 acres of coastal land between the estuary of the River North Esk northward to the mouth of the Woodston Burn. It consists of a sandy foreshore, with rocks at the north end, a line of dunes, a salt marsh (a former channel of the North Esk), dune pasture and cliffs. The cliffs reach a height of $200 \mathrm{ft}$; ; southwards of St. Cyrus village they lie inland behind the dunes, but at the north end of the Reserve they rise directly from a rocky foreshore. The primary interest of the Reserve is botanical. More than 300 species of plants are recorded for the area, many of these being near the northern limits of their range in Britain. The physical features, good soil, and climate combine to favour the establishment of a variety of plant communities remarkably rich in species for such a coastal strip in north-east Scotland. The cliffs support a particularly attractive and interesting flora, with more than 170 species of flowering plants, including clustered campanula, great mullein, hemp agrimony, henbane, viper's bugloss, Nottingham catchfly, marjoram, hairy violet and maiden pink.

The Reserve was declared by nature reserve agreements with the owners, the Tay Salmon Fisheries Co., Ltd., and Joseph Johnston and Sons.

\section{Beinn Eighe (Extension), Ross and Cromarty}

This fifty-seven acre strip of pinewood and moorland between the main Kinlochewe-Gairloch road (A.832) and the shore of Loch Maree runs from the east end of the Loch to the estuary of the Grudie River. The Beinn Eighe Reserve, the first in Britain, was established in 1951 primarily for the protection and rehabilitation of Coille na Glas Leitire, the relict pinewood on the west side of the main road from which, by historical accident, the present area had been severed under different ownership. The new addition is ecologically an integral part of the main woodland, and contains some fine mature Scots pine with flora and fauna characteristic of western pinewoods, and of the loch margin. Included in the fauna are the pine marten, wild cat and crossbill.

The extension was declared under a nature reserve agreement with the owner, Colonel W. H. Whitbread. 